\title{
THE EFFECT OF DEBT TO EQUITY RATIO (DER), CURRENT RATIO (CR), AND GROWTH ASSETS ON DIVIDEND POLICY IN CONSUMER GOODS MANUFACTURING COMPANIES WHICH IS LISTED IN THE STOCK EXCHANGE INDONESIA 2015-2017 PERIOD
}

\author{
Jasinta Mustika Sianipar ${ }^{1^{*}}$, Tina Adelina Sinaga ${ }^{2}$ \\ Agustina Sitompul ${ }^{3}$, Marisah Rambe 4 , \\ Jholant Bringg Luck Amelia Br Sinaga ${ }^{5}$. \\ Universitas Prima Indonesia Medan \\ *e-mail: sianiparjasinta@gmail.com
}

\section{INFO ARTIKEL}

Histori Artikel :

Tgl. Masuk : 17 Juli 2020

Tgl. Diterima : 16 September 2020

Tersedia Online : 29 September 2020

Keywords:

Debt To Equity Ratio (Der), Current

Ratio (Cr), And Asset Growth (AG)

Against Dividend Policy.

\section{ABSTRAK/ABSTRACT}

The existence of this observation is to see the effect of Debt To Equity Ratio, Current Ratio, and Asset Growth on the Devidend Payout Ratio of the consumer goods sector listed on the IDX. This research belongs to a quantitative approach, the type of research used is descriptive quantitative and its nature is based on explanatory explanations. The population is 50 companies and a sample of 19 companies. The data techniques are documentation and source of IDX financial reports. This research was tested with using multiple linear regression. Before testing, data testing will be tested using the classical assumption test. The results obtained in this study indicate that simultaneously the Debt To Equity Ratio, Current Ratio, and Asset Growth have a positive effect on the Dividend Payout Ratio. Partially, Debt To Equity Ratio and Current Ratio have a positive and significant effect on the Dividend Payout Ratio. Meanwhile, Asset Growth has no and insignificant effect on the Dividen Payout Ratio. so every increase / decrease in Current Ratio, and Debt to Equity Ratio has an effect on the Devidend Payout Ratio.

\section{PENDAHULUAN}

Berdasarkan beberapa perusahaan telah bertumbuh di era globalisasi. Adanya tingkat persaingan yang begitu tinggi tentunya harus diikuti dengan adanya motivasi tinggi serta mampu menyesuaikan perubahan yang terjadi, sehingga dapat berjalan dengan efesiensi maka memperoleh profit yang mencapai target.

Investasi sangat menarik perhatian saat ini. Sehingga pada Bursa Efek
Indonesia menjadi pusat sarana bagi masyarakat berinvestasi. Perusahaan yang dapat bertahan dalam tekanan dan krisis dan cenderung stabil adalah perusahaan consumer goods sehingga menjadi pilihan bagi setiap pemegang saham. Adanya keuntungan investor yaitu berupa dividen, sehingga menimbulkan kepercayaan berinvestasi. Faktor yang mempengaruhi nilai perusahaan dalam tingkat pembayaran dividen berhubungan dengan penilaian para pemegang saham dalam melihat kemampuan perusahan untuk membayar 
dividen yang dapat diukur menggunakan rasio DPR. Debt to Equity Ratio membuktikan modal pemilik dapat menutupi hutang danseberapa besar kemampuan perusahaan membayar kewajibannya, karena akan mempengaruhi laba dan pembagian suatu dividen. Bagi seorang investor,melakukan investasi pada suatu sekuritas yang telah dipilih tentu mengharapkan dapat memperoleh tingkat pengembalian (return) yang sesuai dengan resiko yang harus ditanggung oleh para investor. Bagi para investor tingkat return merupakan faktor utama karena return adalah hasil yang diperoleh dari suatu investasi (Hartono, 2010).

Current Ratio perusahaan yaitu kemampuan perusahaan untuk memenuhi kewajiban financialnya dalam jangka pendek dengan dana lancar yang tersedia (Wiagustini, 2010). Likuiditas diukur dengan menggunakan Current ratio. Semakin besar tingkat likuiditasnya, semakin besar kemungkinan dividen yang akan dibayar kepada pemegang saham mengacu kepada ketersediaan kas dimana laba ditahan, maka demikian posisi pada current ratio menunjukan bagaimana perusahaan membayar current leabilities yang jatuh tempo dan kemampuan pembayaran dividen.

Pertumbuhan aset menunjukan semakin cepat peningkatan perusahaan untuk membiayai, maka sebuah perusahaan menahan pendapatannya dari laba pembagian dividen.

Kebijakan dividen berpengaruh pada nilai perusahaan dikarenakan adanya pembagian saham sebagai dividen atau laba ditahan guna investasi dimasa datang. Pertumbuhan aset menunjukan semakin cepat peningkatan perusahaan untuk membiayai, maka sebuah perusahaan akan menahan pendapatannya dari laba pembagian dividen Menyangkut mengenai pendapatan berupa dividen, investor lebih menyukai dividen yang stabil karena hal tersebut akan meningkatkan kepercayaan investor terhadap perusahaan yang bersangkutan (Sandy dan Asyik, 2013).

Pada PT Mayora Indah Tbk tahun 2016-2017 utang mengalami kenaikan sebesar Rp. 904.367.562.172 atau $13.58 \%$ disaat bersamaan dividen mengikuti peningkatan Rp. 206.129.297.525. atau $74.97 \%$. Pada tahun 2016-2017 adanya kenaikan Rp.1.934.416.821.202 atau $25.95 \%$ dan terhadap total asset adanya peningkatan Rp.1.993.427.941.109 atau $15.42 \%$.

Pada tahun 2015-2016 PT. Delta Djakarta Tbk mengalami kenaikan pada current assets sebesar Rp.146.126.864 atau $16,2 \%$. Namun disaat bersamaan terjadi pengurangan dividen sebesar Rp.60.843.839 atau 38,78\%. tetapi tahun 2015-2016 terjadi penurunan hutang sebesar Rp.3.277.793 atau 1,73\% dan pada total asset juga mengalami kenaikan secara bersamaan sebesar Rp.159.474.734 atau $15,3 \%$

Pada tahun 2016-2017 PT. Sekar Laut Tbk terjadi kenaikan pada total asset sebesar Rp. 68.044.270.259. atau 11.97\%. Disaat bersamaan tahun 2016-2017 dividen menurun sebesar Rp.1.036.110.750. atau $25 \%$. Tetapi pada tahun 2016-2017 kewajiban dan aktiva lancarnya mengalami peningkatan secara bersamaan.

Dariuraian diatas, maka penelitian ini $b$ erjudul:" Pengaruh Debt To Equity Ratio $(D E R)$, Current Ratio (CR), Assets Growth (AG) terhadap Kebijakan Dividen pada perusahaan Manufaktur Sektor Consumer Goods Yang Terdaftar di Bursa Efek Indonesia".

\section{KERANGKA TEORITIS DAN PENGEMBANGAN HIPOTESIS}

\section{Teori Pengaruh Debt To Equity Ratio Terhadap Kebijakan Dividen}

Pembahasan tentang struktur modal terdapat suatu perubahan dalam komposisi pendanaan dapat berdampak terhadap nilai perusahaan jika ketetapan penanaman modal dan kebijakan dividen dilakukan secara konsisten. (Husnan dan Pudjiastuti 2012:279), Apabila kewajiban meninggkat, perusahaan membagikan dividen semakin menurun. (Hery 2013:37), Apabila memiliki pendapatan lebih besar dari dana yang di pinjam dari suku bunga yang akan dibayar pada kreditor dan sisa pendapatan akan 
menambah pengembalian atau imbal hasil dari pemilik. (Hery 2015:191), Hasil penelitian ini didukung oleh Morris Witaradya E.S (2012), Mehta (2012), Catarina (2017). menemukan adanya pengaruh secara parsial dan signifikan antara variabel DER terhadap variabel DPR.

\section{Teori Pengaruh Current Ratio Terhadap Kebijakan Dividen}

Suatu dividen menjadi arus kas keluar. Peningkantan likuiditas dan total kas yang tersedia maka besar total nilai perusahaan dalam membagikan dividen. (Mulyawan 2015 : 258-259). Pada suatu perusahaan dinyatakan memiliki penempatan jangka pendek yang baik jika dapat membayar hutang jangka pendek dan dividen. (Jumingan 2015:123). dengan ratio likuiditas dari manajemen dapat memperhatikan jumlah ketersediaan kas khususnya yang berhubungan pada kewajiaban yang akan jatuh tempo. Disamping nilai perusahaan pihak investor juga sangat berperan dalam rasio likuiditas terutama hal pembagian dividen tunai. (Hery 2015:177), Hasil penelitian ini didukung oleh Maulida \& Azhari (2014), Darmawati \& Dillak (2018), Wijaya \& Dzajuli (2013). Menemukan adanya pengaruh secara parsial dan signifikan antara variabel CR terhadap DPR.

\section{Teori Pengaruh Asset Growth Terhadap Kebijakan Dividen}

Apabila pertumbuhan perusahaan semakin meningkat maka akan semakin bertambah kebutuhan dana dalam pembiayaan ekspansi. Kemajuan terhadap perusahaan akan berpengaruh pada nilai aktiva dan semakin bertambah dalam hasil oprasional yang akan di capai. (Sartono 2010:248). Apabila perusahaan semakin meningkat maka kebutuhan perusahaan semakin besar untuk pendanaan ekspansi aset perusahaan menahan laba dibadingkan membayar dividen. (Mulyawan 2015:259). untuk mencapai nilai perusahaan dan pemberian dividen dengan hasil positif, perusahaan besar harus memperhatikan akses pasar yang baik untuk pembayaran dividen yang cukup besar terhadap shareholders. (Lanawati dan Amilin 2015:58). Larasati (2014). Secara parsial tidak berpengaruh dan signifikan maka hipotesis penelitian ini tidak terbukti.

Kerangka konseptual dapat di lihat di bawah dengan mengemukakan jawaban masalah yang diajukan, dan jawaban itu akan diketahui dalam perumusan.

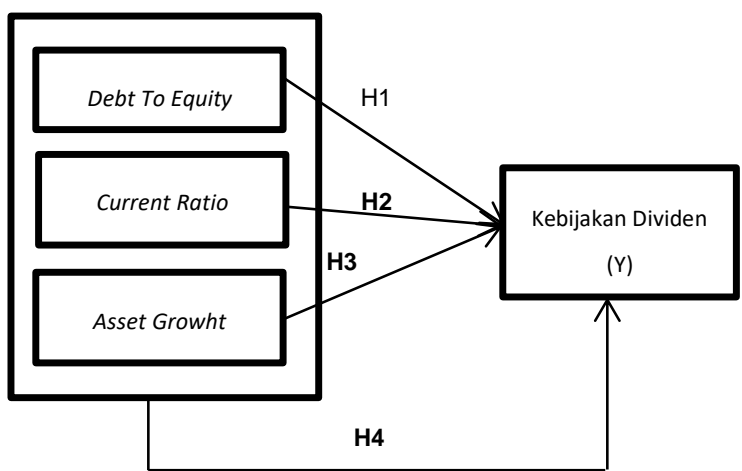

1. $\mathrm{H}_{1}$ : Secara parsial Debt to Equity Ratio berpengaruh terhadap kebijakan dividen.

2. $\mathrm{H}_{2}$ : Secara parsial Current Assets berpengaruh terhadap kebijakan dividen.

3. $\mathrm{H}_{3}$ : Secara parsial Assets Growth berpengaruh dan signifikan terhadap kebijakan dividen.

4. $\mathrm{H}_{4}$ : Debt To Equity Ratio, Current Ratio, Asset Growth berpengaruh secara simultan.

5.

\section{METODOLOGI PENELITIAN Pendekatan Penelitian}

Penelitian ini menggunakan metode pendekatan kuantitatif. Menurut Sugiyono (2016:7) metode positivistic digunakan untuk penelitian berupa angka dan analisis berupa statistik, dan jenis penelitian ini adalah deskriptif kuantitatif. Menurut Sanusi (2017 : 13), penelitian deskriptif kuantitatif adalah desain penelitian yang disusun dalam rangka memberikan gambaran secara sistematis tentang informasi ilmiah yang berasal dari subjek atau objek penelitian. Jumlah sample pada penelilian ini adalah 19 dikali 3 periode tahun penelitian sebesar 57 observasi pada 
perusahaan barang konsumsi. Yang artinya perushaan yg jadi sampel pada penelitian ini memenuhi pertimbangan kriteria sebagai berikut:

Tabel III.1

Sampel Penelitian

\begin{tabular}{|l|l|c|}
\hline No. & \multicolumn{1}{|c|}{ Kriteria } & Jumlah \\
\hline 1 & $\begin{array}{l}\text { Perusahaan manufaktur } \\
\text { sektor consumer goods pada } \\
\text { BEl periode 2015-2017. }\end{array}$ & 50 \\
\hline 2 & $\begin{array}{l}\text { Perusahaan manufaktur } \\
\text { sektor consumer goods yang } \\
\text { tidak mempublikasikan } \\
\text { lengkap laporan keuangan } \\
\text { periode 2015-2017. }\end{array}$ & \\
\hline 3 & $\begin{array}{l}\text { Perusahaan manufaktur } \\
\text { sektor consumer goods yang } \\
\text { tidak mendapat keuntungan } \\
\text { periode 2015-2017. }\end{array}$ & \\
\hline 4 & $\begin{array}{l}\text { Perusahaan manufaktur } \\
\text { sektor consumer goods yang } \\
\text { tidak membagikan dividen } \\
\text { periode 2015-2017. }\end{array}$ & \\
\hline & Total Sampel \\
\hline
\end{tabular}

Sumber : Ghozali (2013:110)

Teknik Pengumpulan Data

Teknik penelitian dilakukan dengan pengumpulan data dan kepustakaan Menurut Sugiyono (2016 : 137) metode dokumentasi merupakan laporan keuangan perusahaan manufaktur sektor consumer goods yang terdaftar di BEI 2015-2017.

\section{Uji Asumsi Klasik \\ Uji Normalitas}

Menurut Ghozali (2016:154) uji normalitas Jika variabel mempunyai nilai distribusi normal atau tidak dapat dilakukan menggunakan one sampel kolmogorov smirnov. dengan ketentuan tingkat signifikan diatas 0.05 maka data berikut normal dan sebaliknya.

\section{Analisis Grafik}

Cara mengetahui normalitas residual yaitu melihat grafik histogram yang membandingkan antara dua observasi dengan distribusi yang mendekati distribusi normal.

\section{b. Analisis Statistik}

Uji normalitas menggunakan grafik dapat menjerumuskan, sesecara statistik dapat sebaliknya. Uji statistik yang digunakan yaitu uji K-S dengan membuat hipotesis:

$\mathrm{HO}$ : Data residual berdistribusi normal

$\mathrm{Ha}$ : Data residual tidak berdistribusi normal. Uji Multikolinieritas

Menurut Ghozali (2016:103) mengetahui uji multikolonieritas ditemukan adanya kolerasi antara variabel independen.

Multikolonieritas dilihat pada nilai tolerance dan VIF. Jika nilai tolerance rendah begitu juga nilai VIF tinggi (karena $\mathrm{VIF}=1 /$ tolerance). Nilai menunjukkan multikolonieritas ialah nilai tolerance $\geq 0,10$ atau nilai VIF $\leq 10$.

\section{Uji Autokorelasi}

Menurut Ghozali (2016:107) uji autokorelasi terjadi karena adanya obsevasi yang berkaitan satu dengan yang lain. $\mathrm{HO}$ : residual (res_1) random (acak). $\mathrm{Ha}$ : residual (res_1) tidak rendom.

\section{Uji Heteroskedastisitas}

Menurut Ghozali (2016:134) mengetahui model regresi terjadi ketidak nyamanan varian dan residual satu pengamatan pada pengamatan lain. Jika adanya variabel yang berbeda dinyatakan heteroskedastisitas.

\section{Model Analisis Data Penelitian}

Pengujian hipotesis analisis regresi linier berganda untuk mengkaji dampak variabel independen terhadap variabel independen. Bentuk regresi yang digunakan yaitu:

\section{$Y=\alpha+b_{1} X_{1}+b_{2} X_{2}+b_{3} X_{3}+e$ \\ Pengujian Hipotesis Secara Silmutan (Uji-F)}

Menurut Ghozali (2016:96) Uji berikut ini menunjukan suatu variabel independen secara bersama terhadap variabel dependen/terikat sebagai berikut yaitu:

Tingkat signifikansi 0.05 dengan derajat bebas ( $\mathrm{n}-\mathrm{k})$ dimana,

1. $n$ : jumlah pengamatan

2. k: jumlah variabel.

\section{Pengujian Hipotesis Secara Parsial (Uji-} t)

Menurut Ghozali (2016:96), uji t menunjukan sejauh mana pengaruh variabel bebas yang dimasukan dalam model terikat/dependent:

1. Jika $t_{\text {hitung }}<t_{\text {tabel, }}\left(\mathrm{H}_{0}\right.$ diterima $)$. 
Jika $t_{\text {hitung }}>t_{\text {tabel, }}\left(\mathrm{H}_{0}\right.$ ditolak $)$.

\section{HASIL DAN PEMBAHASAN}

HASIL PENELITIAN

Statistik Deskriptif

Tabel 1

Statistik Deskrptif

\begin{tabular}{ll|l|l|l|l}
\multicolumn{5}{c}{ Descriptive Statistics } & \multicolumn{2}{l}{} \\
& $\mathrm{N}$ & Min & Max & Mean & Std. Deviation \\
\hline Der & 57 & .076125 & 2.65455 & .70186992 & .613577783 \\
& & & 2 & & \\
\hline Cr & 57 & .584216 & $\begin{array}{l}9.27653 \\
5\end{array}$ & 3.2770226 & 2.156195461 \\
\hline Ag & 57 & - & .685618 & .11182009 & .136068752 \\
\hline Dpr & 57 & .004406 & 1.54168 & .46769357 & .343362957 \\
\hline $\begin{array}{l}\text { Vali } \\
\text { d N }\end{array}$ & 57 & & 8 & & \\
\hline Sum & & & & & \\
\hline
\end{tabular}

Sumber :Data SPSS, 2019

Dari hasil statistic pada tabel IV.I diatas, dinyatakan yaitu:

Bahwa hasil dari observasi (N) 57 data. Yang artinya hasil observasi dalam data Statistik Deskripstif yang dilakukan pada laporan keuangan perusahaan Consumers Goods selama Periode 20152017.

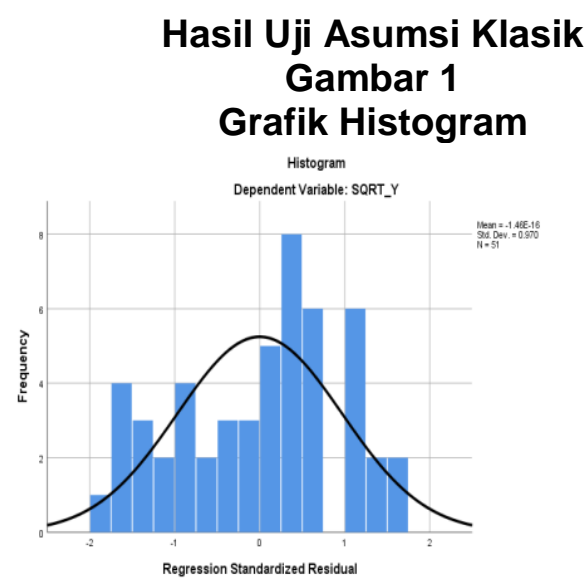

Sumber: Data SPSS, 2019

Gambar IV.1 Kurva bermodel lonceng seimbang dan tidak miring. Yang dapat dilihat pada data terdistribusi dan memenuhi asumsi normalitas.

\section{Gambar 2}

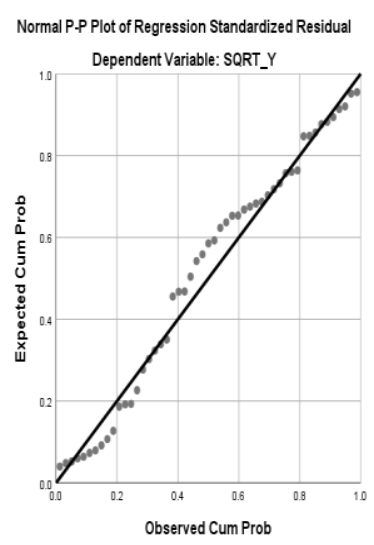

\section{Sumber : Data SPSS, 2019}

Pada grafik P-P Plots gambar IV.2 titik mengikuti arah garis diagonal yang membuktikan pola data terdistribusi normal, dan dapat dilihat pada hasil KolmogorovSmirnov yang memenuhi ketentuan hasil normalitas.

\section{Tabel IV.2}

Hasil One-Sample Kolmogorov Smirnov Test

One-Sample Kolmogorov-Smirnov Test

\begin{tabular}{lll} 
& & Unstandardized Residual \\
\hline $\mathrm{N}$ & \multicolumn{1}{c}{51} \\
\hline Normal & Mean & .0000000 \\
\cline { 2 - 3 } $\begin{array}{l}\text { Parametersa, } \\
\mathrm{b}\end{array}$ & Std. Deviation & .24656981 \\
\hline Most Extreme & Absolute & .098 \\
\cline { 2 - 3 } Differences & Positive & .077 \\
\cline { 2 - 3 } & Negative & -.098 \\
\hline Test Statistic & & .098 \\
\hline Asymp. Sig. (2-tailed) & $.200 \mathrm{c}, \mathrm{d}$ \\
\hline Sumber : Data SPSS,2019
\end{tabular}

Sumber : Data SPSS,2019

Untuk mengetahui Variabel Dependen dan Independen berdistribusi Normal atau tidak jika Asymp. Sig lebih besar dari 0.05 antara lain dapat menggunakan Kolmogorov-Smirnov.

Hasil Kolmogorov-Smirnov 0.098 dan jumlah Asymp.Sig. (2-tailed) $>0.05$ yaitu 0.200 , maka mempunyai residual yang terdistribusi normal.

Multikolinearitas

Berfungsi untuk mengetahui masalah Uji Multikolinearitas dengan cara melihal hasil tolerance $<0.1$ dan Nilai VIF>10 maka tidak terjadi Multikolinieritas 


\section{Hasil Uji Multikolinieritas}

\begin{tabular}{l|l|l}
\multicolumn{3}{c}{ Coefficientsa } \\
Model & $\begin{array}{l}\text { Correlations } \\
\text { Tolerance }\end{array}$ & VIF \\
\hline (Constant) & & \\
\hline SQRT_X1 & .232 & 4.306 \\
\hline SQRT_X2 & .234 & 4.271 \\
\hline SQRT_X3 & .963 & 1.038 \\
\hline
\end{tabular}

Sumber: Data SPSS, 2019.

Hasil tabel IV.3 yang diperoleh variabel $\mathrm{X}_{1}, \mathrm{X}_{2}, \mathrm{X}_{3}$ dengan nilai berada dibawah 10 hasil uji multikolinearitas dinyatakan semua variabel independen ada diatas 0.10. Dari penelitian ini bebas dari multikolinearitas.

\section{Uji Autokorelasi}

Hasil yang diperoleh dari Model Regresi Linear dapat melihat nilai Durbin Watson (DW) tabel pada tabel Summary dengan bandingkan Durbin Upper (DU) dan nilai Durbin Lower (DL).

\section{Tabel 4}

\section{Model Summaryb}

\section{Hasil Uji Autokorelasi}

\begin{tabular}{l|l} 
Model & Durbin-Watson \\
\hline 1 & 1.902 \\
\hline
\end{tabular}

Sumber: Data SPSS, 2019

Tabel IV.4 , bisa diamati nilai yang di peroleh adalah sebesar 1.902. setelah dihitung mendapatkan jumlah $\mathrm{dL}=1.4637$, $\mathrm{dU}=1.6845$ dan $4-\mathrm{dU}=2.3155$, maka $\mathrm{dU}<$ $\mathrm{d}<4-\mathrm{dU}(1.6845<1.902<2.3155)$ menunjukkan bahwa tidak terjadi autokorelasi positif atau negatif.

\section{Gambar 3}

\section{Hasil Uji Heterokedastisitas Dengan} Grafik Scatterplot

Bertujuan untuk melihat adanya ketidaksamaan antara varian Residual dalam pengamatan Model Regresi Linear dalam mengetahui tidak terjadinya heterokedasitas.

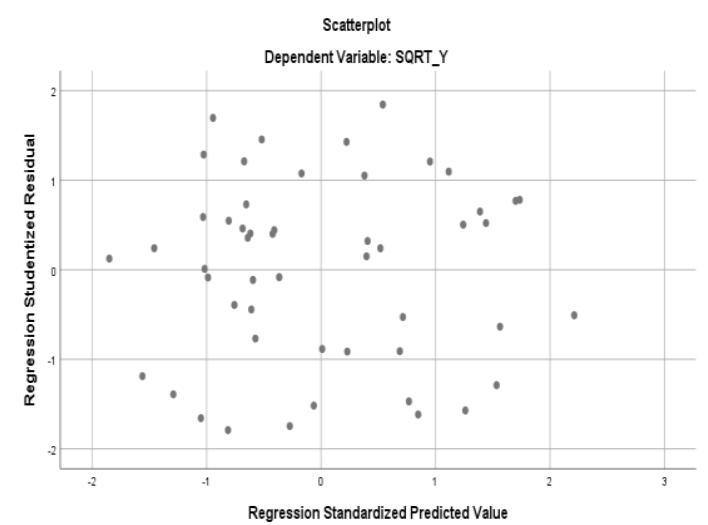

\section{Sumber :Data SPSS, 2019}

Menurut gambar IV.3 titik meluas sembarangan berada diatas maupun dibawah angka 0 pada sumbu $Y$. disimpulkan data tidak terjadi heterokedastisitas.

\section{Tabel 5}

\section{Hasil Uji Heteroskedastisitas (Uji Glejser)}

Untuk mengetahui antara variabel independen dengan nilai absolut lebih dari 0.05 maka tidak terjadi Heteroskedastisitas.

\begin{tabular}{|c|c|c|c|c|c|}
\hline \multicolumn{6}{|c|}{ Coefficientsa } \\
\hline \multirow[b]{2}{*}{ Model } & \multicolumn{2}{|c|}{ Unstandardize } & \multirow{2}{*}{ 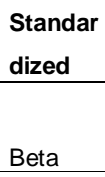 } & \multirow[b]{2}{*}{$t$} & \multirow[b]{2}{*}{ Sig. } \\
\hline & B & Error & & & \\
\hline - (Constant & .198 & .208 & & .950 & .347 \\
\hline SQRT_X1 & .072 & .116 & .182 & .615 & .542 \\
\hline SQRT_X2 & .004 & .070 & .015 & .051 & .960 \\
\hline SQRT_X3 & -.157 & .134 & -.170 & -1.170 & .248 \\
\hline
\end{tabular}

Sumber : Data SPSS, 2019

Tabel IV.5 variabel Debt To Equity Ratio (DER) mempunyai signifikan 0.542 , Current Ratio (CR) 0.960, Asset Growth (AG) 0.248 tidak terdapat heteroskedastisitas dengan variabel independen diatas 0.05 .

\section{Hasil Analisis Data Penelitian Model Penelitian}

Dapat diketahui hubungan antara variabel independent dengan variabel dependen berhubungan positif atau negatif dalam mengalami kenaikan atau penurunan, jadi variabel yang telah diteliti pengaruh Debt to Equity Ratio,Current ratio,dan Asset Growth terhadap Devident Payout Ratio, hasilnya dapat dilihat yaitu:

Tabel 6

Regresi linear berganda 


\begin{tabular}{lll|l|l|l|}
\multicolumn{7}{c}{ Unstandardized } & \multicolumn{1}{c}{} & \\
Model & B & $\begin{array}{l}\text { Std. } \\
\text { Error }\end{array}$ & Beta & T & \multicolumn{1}{c}{ Sig } \\
\hline (Constant) & -.460 & .399 & & -1.152 & .255 \\
\hline SQRT_X1 & .624 & .223 & .776 & 2.792 & .008 \\
\hline SQRT_X2 & .376 & .135 & .770 & 2.780 & .008 \\
\hline SQRT_X3 & -.202 & .257 & -.107 & -.786 & .436 \\
\hline
\end{tabular}

Sumber: Data SPSS, 2019

Tabel IV.6 bagian kolom B memiliki persamaan linear berganda sebagai berikut:

1. Constant $(a)=0.460$ konstanta (a) memiliki koefisien regresi 0.460 . yang dimaksud apabila variabel $\mathrm{X} 1, \mathrm{X} 2$, dan $\mathrm{X} 3$ ditafsir nol, jadi jumlah $Y$ sebesar 0.460 .

2. Hasil $b 1=0.624 \mathrm{X} 1$

memiliki koefisien regresi sebesar 0.624. Yang dimaksud setiap bertambah variabel $\mathrm{X} 1$ sehingga terjadi $Y 0.624$

3. Hasil b2 $=0.376 \times 2$

X2 memiliki koefisien regresi positif 0.376. yang dimaksud setiap bertambahnya $X 2$ sehingga terjadi kenaikan Y 0.376 .

4. Hasil $b 3=-0.202 \times 3$

X3 memiliki koefisien regresi negatif 0.202 . jadi setiap kenaikan $X 3$ terjadi penurunan Y 0.202 .

\section{Koefesien Determinasi Hipotesi}

Berdasarkan hasil pengujian pada nilai Adjusted $\mathrm{R}^{2}$ adalah $0,103 \mathrm{Hal}$ ini menunjukkan bahwa 10,3\% variasi variabel Kebijakan Deviden dapat dijelaskan oleh variabel Debt To Equity Ratio, Current Ratio,dan Asset Growth, sedangkan sisanya sebesar $89.7 \%$ merupakan variasi variabel yang tidak dijelaskan dalam penelitian ini.

Tabel 7

Hasil Pengujian Koefisien Determinsi $\left(\mathbf{R}^{2}\right)$

\begin{tabular}{ll|l|l|l|l} 
& & \multicolumn{3}{c}{ Model Summaryb } \\
& & $\mathrm{R}$ & & \\
Mode & & Squa & Adjusted & \\
$\mathrm{I}$ & $\mathrm{R}$ & $\mathrm{re}$ & $\mathrm{R}$ Square & Std. Error of the Estimate \\
\hline 1 & $.396 \mathrm{a}$ & .157 & .103 & .25432 \\
\hline
\end{tabular}

Sumber: Data SPSS, 2019

\section{Pengujian Hipotesis Secara Simultan} (Uji F)
Dengan adanya Uji $F$ dapat mengetahui variabel independen secara simulan terhadap variabel dependen dengan nilai signifikansi $<0.05$. dapat dilihat sebagai berikut:

\section{Tabel 8 \\ Hasil Uji Simultan (Uji F)}

\begin{tabular}{|c|c|c|c|c|c|}
\hline \multicolumn{6}{|c|}{ ANOVAa } \\
\hline Model & $\begin{array}{l}\text { Sum of } \\
\text { Squares }\end{array}$ & Df & $\begin{array}{l}\text { Mean } \\
\text { Square }\end{array}$ & $\mathrm{F}$ & Sig. \\
\hline Regression & .565 & 3 & .188 & 2.912 & $.044 b$ \\
\hline Residual & 3.040 & 47 & .065 & & \\
\hline Total & 3.605 & 50 & & & \\
\hline
\end{tabular}

Sumber: Data SPSS, 2019

Dari hasil nilai $F_{\text {hitung }}>F_{\text {tabel }}$ (2.912>2.78) dan signifikan lebih kecil dari $0.05 \quad(0.044<0.05)$ disimpulkan Debt to Equity Ratio (DER), Current Ratio (CR), Asset Growth secara simultan berpengaruh dan signifikan terhadap Dividend Payout Ratio.

Pengujian Hipotesis Secara Parssial (Uji t)

Menunjukan kebenaran hipotesis penelitian menggunakan Uji t dengan cara memiliki signifikansi $<0,05$. maka dapat memperjelas pengujian hipotesa.

Tabel IV.9

Hasil Uji Parsial (Uji t)

\begin{tabular}{|c|c|c|c|c|c|}
\hline \multicolumn{6}{|c|}{ Coefficientsa } \\
\hline & \multirow{2}{*}{\multicolumn{2}{|c|}{$\begin{array}{l}\text { Unstandardized } \\
\text { Coefficients }\end{array}$}} & \multirow{3}{*}{$\begin{array}{l}\text { Standardized } \\
\text { Coefficients } \\
\text { Beta }\end{array}$} & \multirow[b]{3}{*}{$\mathrm{T}$} & \multirow[b]{3}{*}{ Sig. } \\
\hline & & & & & \\
\hline Model & B & $\begin{array}{l}\text { Std. } \\
\text { Error }\end{array}$ & & & \\
\hline (Constant & -L.460 & .399 & & -1.152 & .255 \\
\hline SQRT_X1 & .624 & .223 & .776 & 2.792 & .008 \\
\hline SQRT_X2 & .376 & .135 & .770 & 2.780 & .008 \\
\hline SQRT X3 & -.202 & .257 & -.107 & -.786 & .436 \\
\hline
\end{tabular}

Sumber :Data SPSS , 2019

Dengan adanya uji t sehingga dapat memberikan pengujian hipotesis secara parsial adalah:

1. Hasil yang diperoleh menyatakan Debt to Equity Ratio $\mathrm{t}_{\text {hitung }}>\mathrm{t}_{\text {tabel }}=$ $2.792>1,67412$ secara parsial Devidend Payout Ratio berpengaruh positif dan signifikan.

2. Hasil yang diperoleh menyatakan Current Ratio $\mathrm{t}_{\text {hitung }}>\mathrm{t}_{\text {tabel }}=2.780>$ 1,67412, secara parsial Current 
Ratio berpangaruh positif dan signitifikan.

3. Hasil yang diperoleh menyatakan Assets Growth $\mathrm{t}_{\text {hitung }}<\mathrm{t}$ tabel $=-0.786$ $<1,67412$, variabel Assets Growth tidak berpengaruh dan tidak signitifikan terhadap Divid end Payout Ratio .

\section{PEMBAHASAN HASIL PENELITIAN}

\section{Pengaruh Debt to Equity Ratio Terhadap Dividend Payout Ratio \\ Dari hipotesis penelitian ini} menyatakan bahwa Debt to Equity Ratio berpengaruh positif dan signifikan terhadap Deviden Payout Ratio. dan hasil peroleh adanya pengaruh Debt to Equity Ratio terhadap Deviden Payout Ratio. Jadi, dapat dinyatakan Debt to Equity Ratio menggambarkan perbandingan hutang dan ekuitas dalam pendanaan perusahaan menunjukan kemampuan sendiri modal perusahaan untuk memenuhi seluruh kewajibannya. (Sawir 2015:13).

Penelitian ini tidak sejalan dengan (Adella G Situmorang (2017)). bahwa Debt to Equity Ratio secara parsial tidak berpengaruh positif kepada Deviden Payout Ratio, sejalan dengan Catarina Dina Eka yang menyatakan bahwa Debt to Equity Ratio berkontribusi dalam kenaikan ataupun penurunan Deviden layout ratio. Berdasarkan pernyataan yang ada suatu perusahaan bukan hanya membiayai aktiva. Serta bukan hanya menanggung beban tetap tetapi melainkan menambah penghasilan.

\section{Pengaruh Current Ratio Terhadap Dividend Payout Ratio}

Dari hipotesis penelitian ini menyatakan bahwa Current Ratio berpengaruh positif dan signifikan terhadap Deviden Payout Ratio. dan hasil yang di peroleh adanya pengaruh Current Ratio terhadap Deviden Payout Ratio. jadi, dapat dinyatakan bahwa Current Ratio suatu perbandingan antara aktiva lancar dengan hutang lancar. (Munawir 2014:72)
Penelitian ini tidak sejalan dengan hasil penelitian terdahulu yaitu yang menyatakan Current Ratio tidak berpengaruh terhadap Dividend Payout Ratio.. (Madarina laili (2015). Hasil penelitian ini sejalan variabel Current Ratio berpengaruh Positif dan signifikan terhadap Dividend Payout Ratio. (Betha Dwi Larasati (2014). Berdasarkan pernyataan yang bahwa membandingkan aktiva lancar dengan kewajiban lancar untuk mengetahui tanggung jawab suatu perusahaan dalam kewajiban jangka pendeknya menggunakan aktiva lancar. Sehingga menjadi point perhatian investor dalam pengembalian dividen.

\section{Pengaruh Asset Growth Terhadap Dividend Payout Ratio}

Dari hipotesis penelitian ini menyatakan bahwa Asset Growth berpengaruh dan signifikan terhadap Deviden Payout Ratio. dan hasil yang di peroleh tidak adanya pengaruh Asset Growth terhadap Deviden Payout Ratio.

Hasil penelitian ini tidak sejalan dengan penelitian terdahulu, Asset Growth berpengaruh negatif dan signifikan terhadap Dividend Payout Ratio. (Luluk Mariyah Ulfa dan Tri Yuniati (2016), Secara parsial penelitian ini tidak berpengaruh negative dan signifikan terhadap Dividend Payout Ratio. berdasarkan pernyataan tersebut maka perusahaan cenderung menahan laba daripada membayarkan dalam bentuk deividen.

\section{KESIMPULAN, SARAN, DAN KETERBATASAN}

\section{KESIMPULAN}

1. Jadi dari hasil yang di peroleh Secara simultan Debt To Equity Ratio, Current Ratio,dan Asset Growth berpengaruh positif dan signifikan terhadap Dividend Payout Ratio perusahaan Consumers Good yang terdaftar di Bursa Efek Indonesia (BEI) periode tahun 2015 -2017.

2. Dari hasil yang diperoleh secara parsial yang memiliki pengaruh sebagai berikut: 
a. Debt To Equity Ratio berpengaruh positif terhadap Dividend Payout Ratio perusahaan Consumers Good yang terdaftar di Bursa Efek Indonesia (BEI) periode tahun 2015 $-2017$.

b. Current Ratio berpengaruh positif terhadap Dividend Payout Ratio perusahaan Consumers Good yang terdaftar di Bursa Efek Indonesia (BEI) periode tahun 2015-2017.

C. Asset Growth tidak berpengaruh dan tidak signifikan terhadap Dividend Payout Ratio perusahaan Consumers Good yang terdaftar di Bursa Efek Indonesia (BEI) periode tahun 2015-2017.

d. Dapat diartikan bahwa setiap kenaikan / penurunan Current Ratio, dan Debt to Equity Ratio berpengaruh terhadap Dividend Payout Ratio.

\section{SARAN}

Dari hasil yang di peroleh peneliti dapat memberi saran sebagai berikut:

1. Diharuskan kepada peneliti berikutnya dalam penelitian lebih lanjut untuk Hasil uji $R$ Square $10.3 \%$ berarti ada variable independent diluar model regresi $89.7 \%$ yang tidak ada pada penelitian ini, diharapkan pada peneliti selanjutnya menggunakan variabel diluar penelitian ini..

2. Bagi perusahaan agar dapat memilih investasi yang tepat dan mampu mengetahui bagaimana perusahaan mampu membagikan deviden.

\section{REFERENCES}

Dillak, Juliana Vaya dan Lativah Ivvan Darmawati. 2018. "Pengaruh Current Ratio, Debt to Equity Ratio, Profitabilitas dan Ukuran Perusahaan terhadap kebijakan deviden". (Study Kasus Pada Perusahaan Manufaktur Subsektor Makanan dan Minuman yang Terdaftar di Bursa Efek Indonesia Periode 2013-2016).
Ghozali, Imam. 2013. Aplikasi Analisis Multivariente Dengan Program SPSS 21.Ed. 7, Semarang : Badan Penerbit Universitas Diponegoro.

Ghozali, Imam. 2016. "Aplikasi Analisis Multivariente Dengan Program SPSS 21". Ed. 7, Semarang: Badan Penerbit Universitas Diponegoro.

Hery. 2013. "Rahasia Pembagian Dividen dan Tata Kelola Perusahaan". Yogyakarta: GAVA MEDIA

Hery. 2015. "Analisis Laporan Keuangan Pendekatan Rasio Keuangan”. Yogyakarta: CAPS

Husnan, Suad dan Enny Pudjiastuti. 2012. Dasar-dasar Manajemen Keuangan. Cetakan keenam. UPP STIM YKPN.

Jogiyanto Hartono. 2010. Teori Portofolio Dan Analisis Investasi. Yogyakarta : BPFE.

Jumingan. 2015. "Analisis Laporan Keuangan". Jakarta: PT. Bumi Aksara

Lanawati, Amilin. 2015. "Cash Ratio, Debt to Equity Ratio, Return On Asset, Firm Size, Growthh dan Dividen Payout Ratio pada Perusahaan Manufaktur di Indonesia.Jurnal Riset Akuntansi dan Perpajakan JRAP".

Larasati, Dwi Betha. 2014. "Pengaruh Debt To Equity Ratio dan Current Ratio Terhadap Deviden Payout Ratio". (Study Kasus Pada Perusahaan Sektor Consumer Goods yang Terdaftar di Bursa Efek Indonesia Tahun 2008-2013). E-jurnal Apresiasi Ekonomi .

Mehta, Anupam. 2012. "AN EMPIRICAL ANALYSISOF DETERMINANTS OF DEVIDEND POLICY EVIDENCE FROM THE UAE COMMPANIES," GLOBAL REVIEW OF ACCOUNTING AND FINANCE.

Mulyawan, Setia. 2015. Pengantar Prof Dr.Najib. "Manajemen Keuangan". Pustaka Setia.

Munawir, 2014. "Analisa Laporan Keuangan". Yogyakarta: Liberty Yogyakarta, 2014

Sandy, A., dan Asyik N. F., 2013, "Pengaruh Profitabilitas dan 
Likuiditas Terhadap Kebijakan Dividen Kas pada Perusahaan Otomotif", Jurnal IImu dan Riset Akuntansi, Vol. 1(1), hal 58-76.

Sanusi, Anwar. 2017. "Metodologi Penelitian Bisnis". Cetakan Keempat. Jakarta: Salemba Empat.

Sartono, Agus. 2010. "Manajemen Keuangan, Teori dan Aplikasi". Ed 4. ogyakarta:BPFE

Sawir, Agnes. 2015. "Analisis Kinerja Keuangan dan Perencanaan Perusahaan". Cetakan Kesepuluh Jakarta:PT. Gramedia Pustaka Utama.

Situmorang, G Adella. 2017. "Pengaruh Profitabilitas, Debt To Equity Ratio, Firm Size, Growth, dan Cash Ratio Terhadap Deviden Payout Ratio". Pada Sektor Barang konsumsi Yang Terdaftar Di Bursa Efek Indonesia Periode 2011-2014. Jurnal IImu Manajemen.

Sugiyono. Metode Penelitian Kuantitatif Kualitatif dan $R \& D$. Bandung: Alfabeta,2012.

Wahyuni, Dina Eka Chatarina. 2017. "Pengaruh Debt To Equity Ratio (DER), dan Earning Per Share Tehadap Deviden Payout Ratio" (DPR) Pada Perusahaan LQ 45 Tahun 2011-2015. Google Schoolar Wijaya, dan Djazuli, 2013, "Pengaruh Return On Investment, Current Ratio, Debt To Equity Ratio Terhadap Dividend payout ratio (Studi pada Perusahaan Manufaktur yang Terdaftar di Bursa Efek Indonesia)", E-Jurnal Universitas Brawijaya.

Witaradya. Moris E.S. 2012. "Pengaruh Current Ratio, Earning Pershare, Debt To Equity Ratio, Return On Equity, Terhadap Kebijakan Deviden" (Study Pada Perusahaan Manufaktur yang Terdaftar di Bursa Efek Indonesia).
Yuniati, Tri dan Luluk Mariyah Ulfa. 2016. "Pengaruh Kinerja Keuangan, Asset Growth dan Firm Size Terhadap Dividen Payout Ratio" Jurnal Ilmu dan Riset Manajemen, Volume 5, No. 5, Mei 2016. 